\section{The \\ implications of Ifris adoption on foreign direct investment in poor countries}

Cătălina Florentina PRICOPE, Bucharest University of Economic Studies,

E-mail: catalina.pricope@gmail.com

\section{Alsstract}

Globalisation has contributed to the acceleration of international capital transactions and has increased investors' need to access homogeneous, reliable and comparable financial reports. The objective of the study is to investigate the impact of International Financial Reporting Standards adoption on foreign direct investment flows in poor countries. In order to achieve this objective, the propensity score matching method was applied on a sample of 38 poor countries between 2008 and 2014. Results indicate that International Financial Reporting Standards adoption has a positive impact on foreign direct investment flows in poor countries.

Keywords: IFRS adoption, foreign direct investment, poor countries, propensity score matching

JEL Classification: F21, G11

To cite this article:

Pricope, C.F. (2017), The implications of IFRS adoption on foreign direct investment in poor countries, Audit Financiar, vol. vol. XV, no. 2(146)/2017, pp. 218-229,

DOI: 10.20869/AUDITF/2017/146/218

To link to this article:

http://dx.doi.org/10.20869/AUDITF/2017/146/218

Received: 02.02.2017

Revised: 23.02.2017

Accepted: 25.02.2017 


\section{Introduction}

Globalisation has contributed to the acceleration of cross-border capital transactions. In this context, foreign direct investment (FDI) has become a tool used by countries in pursuit of economic development. FDI entails a number of important benefits for poor countries, such as the introduction of new production processes, creating connections between different business sectors and enabling domestic companies to access international capital markets (Agrawal, 2013). The increasing degree of interconnection among global capital markets has generated a need for investors to access homogeneous, reliable and comparable financial information. Thus, it became essential to create a common financial language (Rakes and Shilpa, 2013).

The relationship between International Financial Reporting Standards (IFRS) adoption and FDI has been extensively investigated. Numerous studies indicate that the transition to the international accounting framework has led to increased FDI flows, particularly in developing countries (Marquez-Ramos, 2011; Gordon, Loeb and Zhu, 2012; Chen Ding and Xu, 2014). However, little attention has been paid to poor countries. Although, according to the literature, poor countries are part of the developing countries group, they may exhibit certain economic and social particularities relevant to the process of accounting harmonization (Perera, 1989; Irvine and Lucas, 2006). The present study contributes to the literature by examining the relationship between IFRS adoption and FDI growth in poor countries.

The research paper is structured as follows: the first section presents a review of the literature with reference to relevant studies addressing the relationship between IFRS adoption and FDI flows. The second section describes the research methodology and within the third section results are presented and discussed. The last section concludes the study.

\section{Literature review}

A number of studies suggest that FDI contributes to economic development in poor countries (Acaravci and Ozturk, 2012; Adeniyi et al., 2012; Rakes and Shilpa, 2013). Investments tend to be concentrated in less developed countries where higher economic growth rates can be achieved (Rakes and Shilpa, 2013). Scarcity of financial resources has prompted many poor countries to consider FDI as a key tool designed to facilitate the transfer of new production technologies (Hossein and Yazdan, 2013).

The acceleration of cross-border financial flows, between developed countries as well as between developed and developing countries, has contributed to the internationalization of trade, businesses and capital markets (Trabelsi, 2015). In this context, it became vital to develop a single set of accounting standards with the aim to achieve uniformity in financial reporting worldwide (Zeghal and Mhedhbi, 2006).

The literature points to three relationships that can occur between IFRS adoption and FDI growth (Zeghal and Mhedhbi, 2006; Lasmin, 2011; Marquez-Ramos, 2011). The first one is the unidirectional relationship running from IFRS adoption to FDI growth. This relationship implies that the adoption and implementation of the international accounting framework in a country contributes to an increase in FDI flows. The second relationship is the unidirectional one running from FDI growth to IFRS adoption. Under this hypothesis countries are pressured to adopt the international accounting framework as they gradually integrate into the global economy. The third relationship identified is the bidirectional relationship between IFRS adoption and FDI growth. According to this relationship, the two variables are mutually dependent.

Efobi and Nnadi (2015) argue that the use of a single set of global accounting standards reduces information barriers across capital markets. The authors invoke this argument to explain the relationship running from IFRS adoption to FDI growth. Differences between accounting standards may hinder the dynamics of cross-border capital transactions. Most frequently, foreign investors have less informational advantages compared to domestic investors. Consequently, transaction costs are higher for foreign investors. This contributes to a decrease in FDI flows (Efobi and Nnadi, 2015). The role of using a single set of financial reporting standards is to reduce information asymmetries in the investment decision-making process (Chen, Ding and $\mathrm{Xu}, 2014)$.

The transition towards the international accounting framework enables poor countries to access external capital sources (Yu and Wahid, 2014). This in turn should help increase liquidity and stimulate the financing of worthwhile projects (DeFond et al., 2011).

Gordon, Loeb and Zhu (2012) argue that countries FDI inflows can increase if financial statements prepared in accordance with IFRS exhibit a higher level of quality 
than those prepared in accordance with domestic standards. Accounting practices in poor countries are underdeveloped. Therefore, there is a higher probability for poor countries to experience a more significant increase in FDI inflows as a result of IFRS adoption in comparison to developed countries. The authors examine a panel data set of 124 countries between 1996 and 2009. Results indicate that IFRS adoption has led to an increase in FDI inflows.

The hypothesis developed by Gordon, Loeb and Zhu (2012) has been addressed within other studies and tested in various economic contexts. For instance, Chen, Ding and $\mathrm{Xu}$ (2014) examine the relationship between IFRS adoption and FDI growth on a sample of 20 OECD countries between 2000 and 2005. Rakes and Shilpa (2013) analyse the particular case of India. Results of both surveys are consistent with those obtained by Gordon, Loeb and Zhu (2012).

The previous studies provide empirical evidence that IFRS adoption and implementation contribute to FDI growth. However, some authors argue that countries seeking FDI growth are prone to IFRS adoption (for instance Judge, Li and Pinkster, 2010; Lasmin, 2011).

Lasmin (2011) uses the neo-institutional theory developed by DiMaggio and Powell (1983) to predict the likelihood of IFRS adoption by countries due to mimetic institutional pressures caused by FDI growth. The research has revealed that an increase in FDI flows generates the likelihood of IFRS adoption within a country. The observed relationship, however, is not statistically significant.

Guler, Guillen and Macpherson (2002) also use the neoinstitutional theory and empirically prove that the degree of network cohesion contributes to national adoption of international standards. According to the authors, FDI growth increases cohesion between countries involved in a transaction. Consistent with this line of reasoning, Judge, Li and Pinkster (2010) provide empirical evidence to support the theoretical relationship between mimetic pressures generated by FDI growth and IFRS adoption.

The study conducted by Marquez-Ramos (2011) emphasises the importance of examining the bidirectional relationship that might occur between IFRS adoption and FDI growth. The author also argues that there may be a number of factors affecting both variables simultaneously. While analysing the relationship between the adoption of the international accounting framework and FDI growth it is important to control the effects of factors that could affect both variables simultaneously, as this could lead to different results.

In light of the literature that investigates the economic effects of IFRS adoption, the general hypothesis of this study is developed:

H1: IFRS adoption contributes to FDI growth in poor countries.

\section{Research methodology}

\subsection{Propensity score matching}

The relationship between IFRS adoption and FDI growth was examined by means of several methodological approaches. For instance, Gordon, Loeb and Zhu (2012) applied a multivariate linear regression on a panel data set consisting of 208 developed and developing countries between 1996 and 2009. To examine the hypothesis regarding the distinction between the two categories of countries in terms of inward FDI, the authors use a difference-in-difference model.

Lasmin (2012) employs the Cobb-Douglas production function to represent the relationship between physical capital, labour and efficiency. These parameters are used as control variables in estimating the effects of IFRS adoption on trade and investment activities.

Chen, Ding and Xu (2014) apply a gravity model on a sample of 20 OECD countries between 2000 and 2005. The analysis revealed that FDI flows are positively associated with the degree of IFRS compliance of financial statements published by companies.

Over the past years, the propensity score matching method has been frequently applied in accounting and finance research (Tucker, 2011). For instance, Gassen and Sellhorn (2006) use propensity score matching to investigate the determinants and effects of IFRS adoption on a sample of German companies. DeFond et al. (2014) use the propensity score matching method to examine the extent to which IFRS adoption affects the frequency of negative returns reported by publicly traded companies.

In the present study, the research hypothesis is tested by means of the propensity matching method (Rosenbaum and Rubin, 1983). This methodological 
approach allows comparisons between countries with similar characteristics.

The use of the propensity score matching method in the analysis of the relationship between IFRS adoption and FDI growth has two methodological advantages compared to the classic linear regression model. First, the propensity score matching method is nonparametric. Therefore, it is not necessary to specify a parametric relationship between the dependent variable and independent variables included in the analysis. Second, this method reduces the number of untreated observations (in the case IFRS non-adopters) to a subsample of treated observations with similar characteristics (IFRS adopters) (Tucker, 2011). These properties of the propensity score matching method prevent errors in estimating the average treatment effect of the treated observations (Balsmeier and Vanhaverbeke, 2016).

Testing the research hypothesis involves identifying the extent to which IFRS adoption contributes to FDI growth. In the analysis based on propensity score matching the main indicator is the average treatment effect defined by Rosembaum and Rubin (1983) as:

$$
\alpha=E\left(r_{i}^{1}-r_{i}^{0}\right) \text {, }
$$

where $r_{i}^{1}$ represents the reaction of unit $i$ if it has been treated $(\mathrm{T}=1)$ and $r_{i}$ represents the reaction of unit $i$ in case the treatment $(T=0)$ has not been applied.

By adapting equation (1) in accordance with the research question of the present study, the following equation is obtained:

$$
\alpha=E\left(F D I_{i}^{1}-F D I_{i}^{0}\right),
$$

where $F D I^{1}$ and $F D / l_{i}$ represent $F D I$ of country $i$ in case it has adopted IFRS $(T=1)$ or if it uses domestic standards for financial reporting purposes $(T=0)$. When estimating the causal effect of IFRS adoption, $F D /{ }^{1}$ and $F D /{ }$ i cannot be observed for the same country simultaneously. According to Rosembaum and Rubin (1983) in this case, equation (1) can be re-written as follows:

$$
\alpha=P\left[E\left(r^{1} \mid T=1\right)-E\left(r^{0} \mid T=1\right)\right]+(1-P)\left[E\left(r^{1} \mid T=0\right)-E\left(r^{0} \mid T=0\right)\right],
$$

where $P$ is the probability to notice observation $i$ for which $\mathrm{T}=1$ within the statistical sample.
Similarly, in the case of the causal inference between IFRS adoption and changes in FDI flows, equation (3) becomes:

$$
\alpha=P\left[E\left(F D I^{1} \mid I F R S=1\right)-E\left(F D I^{0} \mid I F R S=1\right)\right]+(1-P)\left[E\left(F D I^{1} \mid I F R S=0\right)-E\left(F D I^{0} \mid I F R S=0\right)\right]
$$

Propensity scores are estimated through a probit model where the dependent variable is the treatment variable and the independent variables are those on which treated and control observations will be matched (Tucker, 2011). Subsequently to the estimation of the scores that capture similarities between countries, each treated observation is matched with the most similar control observation. Matchings are performed through stratification matching (Becker and Ichino, 2002; Tucker, 2011).

Stratification matching is based on dividing the observations in blocks. The average propensity score is computed for each block of observations. Subsequently, the difference between the average values of the dependent variable is computed for each block of observations based on the following equation:

$$
E_{q}=\sum \frac{i \in I(q) Y_{i}^{T}}{N_{q}^{T}}-\sum \frac{j \in I(q) Y_{i}^{C}}{N_{q}^{C}}
$$

where:

I(q)- observations from block q;

$Y_{T} T_{r}$ value of the dependent variable for the treated observation i;

$Y c_{j}$ value of the dependent variable for the control observation $\mathrm{j}$;

$N^{T}{ }^{-}$number of treated observations in block q; $\mathrm{NC}_{\mathrm{q}}$ - number of control observations in block $\mathrm{q}$.

Within the stratification matching method, the average treatment effect (ATE) is the weighted average of all observed effects in each block and it is computed based on the following equation:

$$
A T E=\sum_{q=1}^{Q} E_{q} \frac{\sum i \in I(q) T_{i}}{\sum \forall i T_{i}},
$$

where $T_{i}$ is the binary variable that indicates if observation $i$ is treated $(T=1)$ or not $(T=0)$ (Becker and Ichino, 2002). 
The main advantage of using the propensity score matching method in solving causal inferences is that it allows improving the conditions of a random experiment in order to estimate the causal effect as in a controlled one (Rosenbaum and Rubin, 1983). This method yields to reliable results only if the conditional independence assumption is satisfied. In this instance, the conditional independence implies that the decision of using a certain set of financial reporting standards is random and uncorrelated with FDI flows, once the vector of exogenous variables effects has been controlled for. The inferences performed through the propensity score matching method are valid only for those values of the propensity score for which matchings between treated and control observations are possible. The interval where these values can be found is called common support region (Tucker, 2011).

\subsection{Research sample}

The sample on which the research hypothesis was tested consists of low income and lower middle income countries (according to the World Bank classification), with active capital markets. The period of time between 2008 and 2014 was analysed in order to control for the effects of the business cycle and due to data availability. The rationale for selecting this sample is represented by the international consensus concerning the low income levels of these countries. Furthermore, the international organizations have undertaken actions for the development of these countries and put pressure on them to adopt an international accounting perspective in order to facilitate the monitoring of implemented programs. Consistent with prior literature, according to which IFRS is relevant only for countries with active capital market (Amiraslani, latridis and Pope, 2013) the sample includes 38 poor countries with active capital markets (Table no. 1). Out of these, 10 require or permit listed companies to use IFRS, 6 adopt IFRS between 2008 and 2014 and 22 apply domestic standards for financial reporting purposes of listed companies. Liberia, Leshoto, Pakistan, Cambodia, Lao, Sierra Leone, Somalia and Syria were not included in the sample because these did not have active capital market during 2008 and 2014. Zimbabwe, Republic of Congo, Ivory Coast, Egypt, Honduras, Kenya, Myanmar, Nicaragua, Nigeria, Papua New Guinea, Uzbekistan and Zambia were not included in the analysis due to data unavailability.

Table no. 1. Sampled countries
Apply IFRS

Source: PwC (2014); Deloitte (2016)

Data were collected from several sources: World Bank datasets (World Bank, 2016a, 2016b, 2016c), the PwC report on IFRS adoption around the world (PwC, 2014), the website lasPlus (Deloitte, 2016), published by Deloitte, which provides information regarding IFRS use within each country and the study conducted by Daniels,
Trebilcock and Carson (2011) which provides information regarding the membership of countries to the former British colony. Table 2 prezents the data source for each variable introduced in the analisys. Data were processed using Stata 12.0 software. 


\subsection{Variables}

The variables used in this study are presented in Table no. 2. The selection of variables was performed using the model developed by Gordon, Loeb and Zhu (2012).
According to the authors, this model includes the factors that are most frequently used in the literature to examine the evolution of FDI flows. Thus, 12 variables, for which it was possible to collect a complete data set were included in the analysis.

\begin{tabular}{|c|c|c|c|c|}
\hline Category & Indicators & Description & Source & References \\
\hline $\begin{array}{l}\text { Foreign direct } \\
\text { investment }\end{array}$ & LnFDI & $\begin{array}{l}\text { Natural logarithm of inward foreign direct } \\
\text { investment. }\end{array}$ & $\begin{array}{l}\text { World Bank } \\
(2016 a)\end{array}$ & $\begin{array}{l}\text { Marquez-Ramos } \\
\text { (2011); Gordon, Loeb } \\
\text { and Zhu (2012); Chen, } \\
\text { Ding and Xu (2014) }\end{array}$ \\
\hline $\begin{array}{l}\text { IFRS adoption } \\
\text { status }\end{array}$ & IFRS & $\begin{array}{l}\text { Dummy variable, takes the value of } 1 \text { for } \\
\text { countries which impose or permit financial } \\
\text { reporting in accordance with IFRS and } 0 \\
\text { otherwise }\end{array}$ & $\begin{array}{l}\text { PwC (2014), } \\
\text { Deloitte (2016) }\end{array}$ & $\begin{array}{l}\text { Marquez-Ramos } \\
\text { (2011); Gordon, Loeb } \\
\text { and Zhu (2012); Chen, } \\
\text { Ding and Xu (2014) }\end{array}$ \\
\hline $\begin{array}{l}\text { Degree of } \\
\text { capital market } \\
\text { development }\end{array}$ & LnGDP & Natural logarithm of GDP. & $\begin{array}{l}\text { World Bank } \\
\text { (2016a) }\end{array}$ & $\begin{array}{l}\text { Marquez-Ramos } \\
\text { (2011); Gordon, Loeb } \\
\text { and Zhu (2012); Chen, } \\
\text { Ding and Xu (2014) }\end{array}$ \\
\hline $\begin{array}{l}\text { Degree of } \\
\text { economic } \\
\text { openness }\end{array}$ & OPEN & $\begin{array}{l}\text { The aggregated value of imports and exports } \\
\text { relative to GDP. }\end{array}$ & $\begin{array}{l}\text { World Bank } \\
(2016 a)\end{array}$ & $\begin{array}{l}\text { Asiedu (2006); Gordon, } \\
\text { Loeb and Zhu (2012) }\end{array}$ \\
\hline $\begin{array}{l}\text { Infrastructure } \\
\text { development } \\
\text { level }\end{array}$ & INFR & $\begin{array}{l}\text { Number of mobile phone subscription per } 100 \\
\text { inhabitants. }\end{array}$ & $\begin{array}{l}\text { World Bank } \\
(2016 a)\end{array}$ & $\begin{array}{l}\text { Asiedu (2006); Gordon, } \\
\text { Loeb and Zhu (2012) }\end{array}$ \\
\hline $\begin{array}{l}\text { Degree of } \\
\text { freedom }\end{array}$ & FREE & $\begin{array}{l}\text { Captures perceptions of the extent to which a } \\
\text { country's citizens are able to participate in } \\
\text { selecting their government, as well as freedom } \\
\text { of expression, and freedom of association; } \\
\text { measured in units ranging from }-2.5 \text { to } 2.5 \text {; } \\
\text { proxy for corporate governance quality }\end{array}$ & $\begin{array}{l}\text { World Bank } \\
\text { (2016b) }\end{array}$ & $\begin{array}{l}\text { Globerman and } \\
\text { Shapiro (2002); Busse } \\
\text { and Hefeker (2007); } \\
\text { Gordon, Loeb and Zhu } \\
\text { (2012) }\end{array}$ \\
\hline $\begin{array}{l}\text { Governance } \\
\text { quality }\end{array}$ & GOV & $\begin{array}{l}\text { Captures perceptions of public services, the } \\
\text { quality of the civil service and the degree of its } \\
\text { independence from political pressures, the } \\
\text { quality of policy formulation and implementation; } \\
\text { measured in units ranging from }-2.5 \text { to } 2.5 \text {; proxy } \\
\text { for corporate governance quality. }\end{array}$ & $\begin{array}{l}\text { World Bank } \\
\text { (2016b) }\end{array}$ & $\begin{array}{l}\text { Globerman and } \\
\text { Shapiro (2002); Busse } \\
\text { and Hefeker (2007); } \\
\text { Gordon, Loeb and Zhu } \\
\text { (2012) }\end{array}$ \\
\hline $\begin{array}{l}\text { Degree of } \\
\text { privatization }\end{array}$ & PRIV & $\begin{array}{l}\text { Captures perceptions concerning the ability of } \\
\text { the government to formulate and implement } \\
\text { sound policies and regulations that permit and } \\
\text { promote private sector development; measured } \\
\text { in units ranging from - } 2.5 \text { to } 2.5 \text {; proxy for } \\
\text { corporate governance quality }\end{array}$ & $\begin{array}{l}\text { World Bank } \\
(2016 b)\end{array}$ & $\begin{array}{l}\text { Globerman and } \\
\text { Shapiro (2002); Busse } \\
\text { and Hefeker (2007); } \\
\text { Gordon, Loeb and Zhu } \\
\text { (2012) }\end{array}$ \\
\hline $\begin{array}{l}\text { Regulation } \\
\text { quality }\end{array}$ & REG & $\begin{array}{l}\text { Captures perceptions of the extent to which } \\
\text { agents have confidence in and abide by the } \\
\text { rules of society, and in particular the quality of } \\
\text { contract enforcement, property rights, the } \\
\text { police, and the courts, as well as the likelihood } \\
\text { of crime and violence.; measured in units } \\
\text { ranging from }-2.5 \text { to } 2.5 ; \text { proxy for corporate } \\
\text { governance quality. }\end{array}$ & $\begin{array}{l}\text { World Bank } \\
\text { (2016b) }\end{array}$ & $\begin{array}{l}\text { Globerman and } \\
\text { Shapiro (2002); Busse } \\
\text { and Hefeker (2007); } \\
\text { Gordon, Loeb and Zhu } \\
\text { (2012) }\end{array}$ \\
\hline
\end{tabular}




\section{Table no. 2. Variables used}

\begin{tabular}{|c|c|c|c|c|}
\hline Category & Indicators & Description & Source & References \\
\hline Corruption level & CORRUPT & $\begin{array}{l}\text { Captures perceptions of the extent to which } \\
\text { public power is exercised for private gain; } \\
\text { measured in units ranging from }-2.5 \text { to } 2.5 \text {; } \\
\text { proxy for corporate governance quality. }\end{array}$ & $\begin{array}{l}\text { World Bank } \\
(2016 b)\end{array}$ & $\begin{array}{l}\text { Globerman and } \\
\text { Shapiro (2002); Busse } \\
\text { and Hefeker (2007); } \\
\text { Gordon, Loeb and Zhu } \\
\text { (2012) }\end{array}$ \\
\hline Income level & INCOME & $\begin{array}{l}\text { Dummy variable, takes the value of } 0 \text { for lower- } \\
\text { middle income countries and } 1 \text { for low income } \\
\text { countries. }\end{array}$ & $\begin{array}{l}\text { World Bank } \\
(2016 c)\end{array}$ & $\begin{array}{l}\text { Zeghal and Mhedhbi } \\
(2006)\end{array}$ \\
\hline $\begin{array}{l}\text { Membership to } \\
\text { the former } \\
\text { British Colony }\end{array}$ & BRIT & $\begin{array}{l}\text { Dummy variable, takes the value of } 1 \text { for former } \\
\text { British colonies and } 0 \text { otherwise. }\end{array}$ & $\begin{array}{l}\text { Daniels, } \\
\text { Trebilcock and } \\
\text { Carson (2011) }\end{array}$ & $\begin{array}{l}\text { Daniels, Trebilcock and } \\
\text { Carson (2011), Poudel, } \\
\text { Hellmann and Perera } \\
\text { (2014) }\end{array}$ \\
\hline
\end{tabular}

\section{Data analisys and results}

Descriptive statistics are presented in Table no. 3. The different values of the mean, median, standard deviation, skewness and kurtosis indicate the absence of symmetry of the data series (Stock and Watson, 2003).

\section{Table no. 3. Descriptive statistics}

\begin{tabular}{|l|r|r|r|r|r|r|r|}
\hline \multicolumn{1}{|c|}{ Variable } & \multicolumn{1}{c|}{ Mean } & \multicolumn{1}{c|}{ Median } & \multicolumn{1}{c|}{$\begin{array}{l}\text { Standard } \\
\text { deviation }\end{array}$} & \multicolumn{1}{c|}{ Minimum } & \multicolumn{1}{c|}{ Maximum } & \multicolumn{1}{l|}{ Skewness } & \multicolumn{1}{c|}{ Kurtosis } \\
\hline LnFDI & 1.0317 & 1.1158 & 1.0565 & -4.8368 & 3.8127 & -0.8155 & 6.7666 \\
\hline IFRS & 0.3609 & 0.0000 & 0.4811 & 0.0000 & 1.0000 & 0.5792 & 1.3355 \\
\hline LnGDP & 23.6751 & 23.3371 & 1.6305 & 20.5318 & 28.3451 & 0.6216 & 3.3467 \\
\hline ECON & 74.6588 & 67.8814 & 30.7638 & 19.1187 & 169.5345 & 0.8102 & 3.0102 \\
\hline INFR & 73.3228 & 70.7345 & 35.8568 & 10.6639 & 149.0691 & 0.2308 & 1.9961 \\
\hline FREE & -0.4131 & -0.3200 & 0.6219 & -1.7800 & 0.9700 & -0.0618 & 2.6095 \\
\hline GOV & -0.4853 & -0.5400 & 0.5180 & -1.8700 & 1.0400 & 0.0683 & 3.3274 \\
\hline PRIV & -0.4139 & -0.3800 & 0.4697 & -1.4900 & 1.1200 & 0.1908 & 3.5233 \\
\hline REG & -0.5284 & -0.4950 & 0.5218 & -1.8200 & 1.0000 & 0.2723 & 0.3018 \\
\hline CORRUPT & -0.5309 & -0.5900 & 0.5277 & -1.5100 & 1.2700 & 1.0137 & 4.1388 \\
\hline INCOME & 0.3947 & 0.0000 & 0.4897 & 0.0000 & 1.0000 & 0.4307 & 1.1855 \\
\hline BRIT & 0.2105 & 0.0000 & 0.4084 & 0.0000 & 1.0000 & 0.1668 & 1.4200 \\
\hline
\end{tabular}

The comparative descriptive statistics (Table no. 4) indicate that there are differences between the two types of observations concerning the mean values of the variables under analysis.

The $t$ test was used to check if the differences between the two types of observations suggested by the descriptive statistics are statistically significant. The test revealed significant differences between treated and control observations regarding the mean value of FDI flows ( $\mathrm{LnFDI}, \mathrm{t}=-2.9977$ ), infrastructure development (INFR, $t=-2.9408)$, degree of freedom (FREE, $t=-2.1247$ ), quality of governance (GOV, $t=-3.2567$ ), degree of privatization (PRIV, $t=-7.3039$ ), quality of regulation (REG, $t=-3.0661)$, income level (INCOME, $t=$ 2,8790 ) and the variable reflecting the membership to the former British colony (BRIT, $t=-9.7458$ ). These results are statistically significant at $5 \%$ significance level. Also, the mean values of the degree of economic openness (OPEN, $t=-1.7313$ ) differ significantly between the two categories of observations at $10 \%$ significance level. 


\begin{tabular}{|c|c|c|c|c|c|c|}
\hline & Variables & Mean & Median & $\begin{array}{l}\text { Standard } \\
\text { deviation }\end{array}$ & Minimum & Maximum \\
\hline \multirow{12}{*}{ 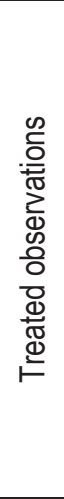 } & LnFDI & 1.2863 & 1.3476 & 0.9016 & -0.6359 & 3.8127 \\
\hline & IFRS & 1.0000 & 1.0000 & 0.0000 & 1.0000 & 1.0000 \\
\hline & LnGDP & 23.5787 & 23.2295 & 1.0718 & 21.8689 & 25.9236 \\
\hline & OPEN & 79.0364 & 69.6348 & 31.9503 & 37.8028 & 146.1061 \\
\hline & INFR & 81.8050 & 84.3143 & 37.1061 & 10.6639 & 144.0822 \\
\hline & LIBER & -0.3060 & -0.2900 & 0.5605 & -1.3100 & 0.9400 \\
\hline & GOV & -0.3501 & -0.5150 & 0.4353 & -0.9500 & 1.0400 \\
\hline & PRIV & -0.1581 & -0.2000 & 0.4463 & -0.9400 & 1.1200 \\
\hline & REG & -0.3998 & -0.3900 & 0.5050 & -1.3600 & 1.0000 \\
\hline & CORRUPT & -0.4635 & -0.5250 & 0.5020 & -1.2300 & 0.8300 \\
\hline & INCOME & 0.2812 & 0.0000 & 0.4519 & 0.0000 & 1.0000 \\
\hline & BRIT & 0.4895 & 0.0000 & 0.5025 & 0.0000 & 1.0000 \\
\hline \multirow{12}{*}{$\begin{array}{l}\frac{\infty}{0} \\
\text { 늠 } \\
0\end{array}$} & LnFDI & 0.8879 & 0.9569 & 1.1115 & -4.8368 & 3.7331 \\
\hline & IFRS & 0.0000 & 0.0000 & 0.0000 & 0.0000 & 0.0000 \\
\hline & LnGDP & 23.7295 & 23.3915 & 1.8747 & 20.5318 & 28.5431 \\
\hline & OPEN & 72.1948 & 65.5903 & 29.8909 & 19.1187 & 169.5345 \\
\hline & INFR & 68.5329 & 67.7092 & 34.3239 & 12.8758 & 149.0691 \\
\hline & LIBER & -0.4736 & -0.3300 & 0.6479 & -1.7800 & 0.9700 \\
\hline & GOV & -0.5617 & -0.5600 & 0.5459 & -1.8700 & 0.6200 \\
\hline & PRIV & $\begin{array}{l}-0.5584 \\
\end{array}$ & -0.4850 & 0.4193 & -1.4900 & 0.3800 \\
\hline & REG & -0.6010 & -0.5900 & 0.5185 & -1.8200 & 0.5900 \\
\hline & CORRUPT & -0.5690 & -0.6200 & 0.5394 & -1.5100 & 1.2700 \\
\hline & INCOME & 0.4588 & 0.0000 & 0.4997 & 0.0000 & 1.0000 \\
\hline & BRIT & 0.0529 & 0.0000 & 0.2245 & 0.0000 & 1.0000 \\
\hline
\end{tabular}

Consistent with the propensity score matching algorithm, the probability of getting the treatment (in this case IFRS adoption) was estimated by means of a probit model. Within the model, the dependent variable is the treatment variable (IFRS), and the exogenous variables are those on the basis of which matching between treated and control observations will be made (Tucker, 2011). The probit model has the following form:

$$
\begin{gathered}
\text { Prob IFRS }=\beta_{0}+\beta_{1} \text { LnGDP }+\beta_{2} \text { OPEN }+\beta_{3} \text { INFR }+\beta_{4} \text { FREE }+\beta_{5} \text { GOV }+\beta_{6} \text { PRIV }+\beta_{7} R E G+\beta_{8} \text { CORRUPT }+ \\
\beta_{9} \text { INCOME }+\beta_{10} \text { BRIT }+\varepsilon_{i},
\end{gathered}
$$

where $\beta_{i}$ are the coefficients of the probit regression and $\varepsilon_{i}$ are the residuals.

Table no. 5 shows the results obtained after running the model on the data set.

Compared to the classic linear regression model, in the case of the probit model, only the signs of coefficients can be interpreted, not their values. Similar to the case of the logit regression, this is because the model is not linear and, therefore, the coefficients change according to the values of the independent variables.

The results of the probit model suggest that the degree of capital market development (LnGDP,
-0.5929 ), the degree of economic openness (OPEN, -0.0149 ), the infrastructure development level (INFR, 0.0162), the degree of privatization (PRIV, 2.0323) and the corruption level (CORRUPT, -1.7722) have a statistically significant impact on the probability that a country adopts IFRS at $5 \%$ significance level. The estimated coefficients suggest that a decrease in the corruption level (CORRUPT), an increase in infrastructure development (INFR) and an increase in the degree of privatization (PRIV) are positively associated with FDI growth. With regard to the degree of capital market development (LnGDP) and the degree of economic openness (OPEN), the 
estimated coefficients indicate that a decrease in these indicators is positively associated with an

increase in the likelihood to adopt IFRS.

Table no. 5. Results of the probit regression

\begin{tabular}{|c|c|c|c|c|}
\hline Sample & $\mathrm{R}^{2}$ & \multirow{2}{*}{$\begin{array}{l}\mathrm{R}^{2} \\
\text { chi }^{2} \text { probability }\end{array}$} & 0.5322 & \\
\hline $\mathrm{chi}^{2}$ & chi2 prok & & \multicolumn{2}{|l|}{0.0000} \\
\hline Variables & Coefficients & Standard error & z statistic & Probability \\
\hline Intercept & 13.1238 & 3.2512 & 4.0400 & 0.0000 \\
\hline LnGDP & -0.5929 & 0.1299 & -4.5600 & 0.0000 \\
\hline OPEN & -0.0149 & 0.0057 & -2.6100 & 0.0090 \\
\hline INFR & 0.0162 & 0.0053 & 3.0400 & 0.0020 \\
\hline FREE & -0.0032 & 0.2471 & -0.0100 & 0.9900 \\
\hline GOV & -0.7795 & 0.6741 & -1.1600 & 0.2480 \\
\hline PRIV & 2.0323 & 0.5720 & 3.5500 & 0.0000 \\
\hline REG & 0.3296 & 0.4941 & 0.6700 & 0.5050 \\
\hline CORRUPT & -1.7722 & 0.5207 & -3.4000 & 0.0010 \\
\hline INCOME & -1.9269 & 0.4061 & -4.7400 & 0.0000 \\
\hline BRIT & 3.4787 & 0.4319 & 8.0500 & 0.0000 \\
\hline
\end{tabular}

The coefficients associated with the dummy variables indicate that the affiliation to the group low income countries (INCOME, -2.9269) decreases a country's' likelihood to adopt IFRS, while former British colonies are more likely to adopt the standards (BRIT, 3.4787). We can be more than $95 \%$ confident that these phenomena were not random and will be reflected by the population.

The chi ${ }^{2}$ probability ratio is 181.95 and has an associated probability of 0.0000 showing that the research model is valid.

Propensity scores were computed using the probit model. Based on these scores, matchings between the two categories of observations were made.

The common support region was determined using the functions implemented in Stata 12.0. Thus, for the data set collected, the common support region is given by the interval $[0.0351,0.9999]$. Observations with propensity scores outside this range were dropped from analysis because it was not possible to find them a match. The final sample size is 197 observations.

In order to apply the stratification matching method, blocks of observations were created using the modules implemented in Stata 12.0. Within each block the average propensity scores of treated and controls must not be significantly different. Thus, six blocks of observations were obtained.

The $t$ test was used to check if errors occurred in the process of creating the blocks of observations, namely if the average propensity scores of treated and control observations differ significantly within each block (Urkaregi, Martinez-Indart and Pijoán, 2014). The differences between the mean values of the propensity scores are not statistically significant at $5 \%$ significance level (Table no. 6). This indicates that treated and control observations were optimally distributed into the six blocks of observations.

Within each block, treated and control observations were matched through stratification matching. Subsequently, the average treatment (IFRS adoption) effect was computed as the weighted average of all observed effects in each block of observations (Table no. 7).

The average treatment effect (ATE) suggests that IFRS adoption has generated on average a 0.4410 units growth in FDI flows in poor countries. The result is statistically significant at $5 \%$ significance level and validates the general hypothesis of this study, according to which IFRS adoption contributes to FDI growth in poor countries. This result is consistent with those obtained by previous studies (Marquez-Ramos, 2011; Gordon, Loeb and Zhu, 2012; Chen Ding and Xu 2014). 


\begin{tabular}{|c|c|c|c|c|c|}
\hline $\begin{array}{l}\text { Blocks of } \\
\text { observations }\end{array}$ & IFRS & $\begin{array}{l}\text { Number of } \\
\text { observations }\end{array}$ & Mean & t-statistic & $p$-value \\
\hline \multirow[t]{2}{*}{ Block 1} & 0 & 61 & 0.0937 & \multirow[t]{2}{*}{0.6983} & \multirow[t]{2}{*}{0.4874} \\
\hline & 1 & 8 & 0.0827 & & \\
\hline \multirow[t]{2}{*}{ Block 2} & 0 & 24 & 0.2915 & \multirow[t]{2}{*}{0.9890} & \multirow[t]{2}{*}{0.3314} \\
\hline & 1 & 5 & 0.2636 & & \\
\hline \multirow[t]{2}{*}{ Block 3} & 0 & 5 & 0.4413 & \multirow[t]{2}{*}{-1.3166} & \multirow[t]{2}{*}{0.2360} \\
\hline & 1 & 3 & 0.4722 & & \\
\hline \multirow[t]{2}{*}{ Block 4} & 0 & 8 & 0.6399 & \multirow[t]{2}{*}{-0.8651} & \multirow[t]{2}{*}{0.4027} \\
\hline & 1 & 7 & 0.6520 & & \\
\hline \multirow[t]{2}{*}{ Block 5} & 0 & 2 & 0.7144 & \multirow[t]{2}{*}{-1.5063} & \multirow[t]{2}{*}{0.1528} \\
\hline & 1 & 15 & 0.7524 & & \\
\hline \multirow[t]{2}{*}{ Block 6} & 0 & 3 & 0.8712 & \multirow[t]{2}{*}{-2.0050} & \multirow[t]{2}{*}{0.0503} \\
\hline & 1 & 50 & 0.9425 & & \\
\hline
\end{tabular}

\section{Table no. 7. Average treatment effect}

\begin{tabular}{|c|c|c|c|c|c|}
\hline Method & $\begin{array}{c}\text { Number of treated } \\
\text { observations }\end{array}$ & $\begin{array}{c}\text { Number of control } \\
\text { observations }\end{array}$ & ATE & $\begin{array}{c}\text { Standard } \\
\text { deviation }\end{array}$ & t-statistic \\
\hline Stratification matching & 88 & 109 & 0.4410 & 0.1540 & $2.8670^{*}$ \\
\hline
\end{tabular}

${ }^{*}$ significant at $5 \%$ significance level.

\section{Ponclusions}

The objective of this study was to examine the relationship between IFRS adoption and FDI growth in poor countries. The general research hypothesis was tested on the sample of 38 poor countries between 2008 and 2014 using the propensity score matching method.

Results are statistically significant at $5 \%$ significance level and suggest that the transition to international accounting framework contributes to FDI growth in poor countries.

The relevance of the research results is subject to limits. First, the initial data collection was possible for only 38 countries. Based on this data a panel data set of 266 observations was obtained. This sample was subsequently reduced to 197 observations which allowed matching. Second, the model estimates the average effect of IFRS adoption on FDI growth once the effects of the vector of exogenous variables have been controlled for. Limited data availability allows us to operationalize ten exogenous variables. According to Tucker (2011), the existence of other exogenous factors omitted from the analysis may affect the validity of the results. Including other factors such as the exchange rate, the interest rate and the cost of labour into the analisys can open new research avenues.

\section{REFERENCES}

1. Acaravci, A. and Ozturk, I. (2012), Foreign direct investment, export and economic growth: empirical evidence from new EU countries, Romanian Journal of Economic Forecasting, vol. 2, pp. 52-67.

2. Adeniyi, O., Omisakin, O., Egwaikhide, F.O. and Oyinlola, A. (2012), Foreign direct investment, economic growth and financial sector development in small open developing economies, Economic Analysis and Policy, vol. 42, no. 1, pp. 105-127, DOI: 10.1016/s0313-5926(12)50008-1.

3. Agrawal, G. (2013), Foreign direct investment and economic growth in BRICS economies: A panel 
data analysis. In Proceedings of 23rd International Business Research Conference, pp. 18-20.

4. Amiraslani, H., latridis, G.E. and Pope, P.F. (2013), Accounting for asset impairment: a test for IFRS compliance across Europe, Centre for Financial Analysis and Reporting Research (CeFARR), [online] Available at: <http://citeseerx. ist.psu.edu/viewdoc/ download?doi=10.1. 1.366.7215\&rep=rep1\&type=pdf> [Accessed 18 December 2016].

5. Asiedu, E. (2006), Foreign direct investment in Africa: The role of natural resources, market size, government policy, institutions and political instability, The World Economy, vol. 29, no.1, pp. 63-77, DOI: 10.1111/j.1467-9701.2006.00758.x.

6. Balsmeier, B. and Vanhaverbeke, S. (2016), International financial reporting standards and private firms' access to bank loans, European Accounting Review, vol. 15, no. 1, pp. 1-30, DOI: 10.1080/09638180.2016.1229207.

7. World Bank (2016a), World Development Indicators [online] Available at: <http://data.worldbank.org/data-catalog/world-developmentindicators $>$ [Accessed 12 September 2016].

8. World Bank (2016b), World Governance Indicators [online] Available at: < http://info.worldbank.org/ governance/wgi/index.aspx\#home > [Accessed 12 September 2016].

9. World Bank (2016c), World Bank Country Classification [online] Available at: $<$ https://datahelpdesk.worldbank.org/knowledgebas e/articles/906519-world-bank-country-and-lendinggroups> [Accessed 12 September 2016].

10. Becker, S.O. and Ichino, A. (2002), Estimation of average treatment effects based on propensity scores, The Stata Journal, vol. 2, no. 4, pp. 358377.

11. Busse, M. and Hefeker, C. (2007), Political risk, institutions and foreign direct investment, European Journal of Political Economy, vol. 23, no. 2, pp. 397-415, DOI: 10.1016/j.ejpoleco.2006.02.003.

12. Chen, C.J., Ding, Y. and Xu, B. (2014), Convergence of accounting standards and foreign direct investment, The International Journal of Accounting, vol. 49, no. 1, pp. 53-86, DOI: 10.1016/j.intacc.2014.01.007.
13. Daniels, R., Trebilcock, M. and Carson, L. (2011), The Legacy of Empire: The common law inheritance and commitments to legality in former British colonies, American Journal of Comparative Law, vol. 59, no. 1, pp. 111-178, DOI: 10.5131/ajcl.2010.0015.

14. DeFond, M.L., Hung, M., Li, S. and Li, Y. (2014), Does mandatory IFRS adoption affect crash risk?, The Accounting Review, vol. 90, no. 1, pp. 265-299, DOI: 10.2308/accr-50859.

15. DeFond, M., Hu, X., Hung, M. and Li, S. (2011), The impact of mandatory IFRS adoption on foreign mutual fund ownership: The role of comparability, Journal of Accounting and Economics, vol. 51, no. 3, pp. 240-258, DOI: 10.1016/j.jacceco.2011.02.001.

16. Deloitte (2016), Adoption of IFRS by country. [online] Available at: < https://www.iasplus.com/en/ resources/ifrs-topics/adoption-of-ifrs > [Accessed 18 November 2016].

17. DiMaggio, P. and Powell, W.W. (1983), The iron cage revisited: Collective rationality and institutional isomorphism in organizational fields, American Sociological Review, vol. 48, no. 2, pp. 147-160, DOI: 10.2307/2095101.

18. Efobi, U. and Nnadi, M. (2015), How Does Foreign Aid Affect the Relationship between IFRS Adoption and Foreign Direct Investment? African Governance and Development Institute Working Paper Series WP/15/014., [online] Available at: <http://papers.ssrn.com/sol3/ papers. cfm? abstract_id=2613810 $>$ [Accessed 1 October 2016].

19. Gassen, J. and Sellhorn, T. (2006), Applying IFRS in Germany: Determinants and consequences, Betriebswirtschaftliche Forschung und Praxis, vol. 58, no. 1, pp. 365-386.

20. Globerman, S. and Shapiro, D. (2002), Global foreign direct investment flows: The role of governance infrastructure, World Development, vol. 30, no. 11, pp. 1899-1919, DOI: 10.1016/s0305-750x(02)00110-9.

21. Gordon, L.A., Loeb, M.P. and Zhu, W. (2012), The impact of IFRS adoption on foreign direct investment, Journal of Accounting and Public Policy, vol. 31, no. 4, pp. 374-398, DOI: 10.1016/j.jaccpubpol.2012.06.001. 
22. Guler, I., Guillén, M.F. and Macpherson, J.M. (2002), Global competition, institutions, and the diffusion of organizational practices: The international spread of ISO 9000 quality certificates, Administrative Science Quarterly, vol. 47, no. 2, pp. 207-232, DOI: $10.2307 / 3094804$.

23. Hossein, S.S.M. and Yazdan, G.F. (2013), FDI and ICT effects on productivity growth, Procedia-Social and Behavioral Sciences, vol. 93, pp. 1710-1715, DOI: 10.1016/j.sbspro.2013.10.104.

24. Irvine, H.J. and Lucas, N. (2006), The rationale and impact of the adoption of International Financial Reporting Standards: the case of the United Arab Emirates, 2006, [online] Available at: $<$ http://ro.uow.edu.au/cgi/viewcontent.cgi?article=1 230\&context=commpapers $>$ [Accessed 22 September 2016].

25. Judge, W., Li, S. and Pinsker, R. (2010), National adoption of international accounting standards: an institutional perspective, Corporate Governance: An International Review, vol. 18, no. 3, pp. 161174, DOI: 10.1111/j.1467-8683.2010.00798.x.

26. Lasmin, R. (2011), An institutional perspective on international financial reporting standards adoption in developing countries, Academy of Accounting and Financial Studies Journal, vol. 15, no. 2, pp. 61-71.

27. Lasmin, R. (2012), The unwanted effects of International Financial Reporting Standards (IFRS) adoption on international trade and investments in developing countries, Journal of Economics and Economic Education Research, vol. 13, no. 1, pp. 1-14.

28. Márquez-Ramos, L. (2011), European accounting harmonization: Consequences of IFRS adoption on trade in goods and foreign direct investments, Emerging Markets Finance and Trade, vol. 47, no. 4, pp. 42-57, DOI: 10.2753/ree1540-496x4705s403.

29. Perera, M.H.B. (1989), Accounting in developing countries: A case for localised uniformity, The British Accounting Review, vol. 21, no. 2, pp. 141157, DOI: 10.1016/0890-8389(89)90193-5.

30. Poudel, G., Hellmann, A. and Perera, H. (2014), The adoption of International Financial Reporting
Standards in a non-colonized developing country: The case of Nepal, Advances in Accounting, vol. 30, no. 1, pp. 209-216, DOI: 10.1016/j.adiac.2014.03.004.

31. PricewaterhouseCoopers (PwC) (2014), IFRS adoption by country, [online] Available at: $<$ https://www.pwc.com/us/en/issues/ifrsreporting/publications/assets/pwc-ifrs-by-country2014.pdf> [Accessed 10 September 2016].

32. Rakesh, H.M. and Shilpa, R. (2013), Effect of IFRS and Financial Statements: Implications on FDI and Indian Economy, International Journal of Commerce, Business and Management (IJCBM), vol. 2, no. 5, pp. 233-241.

33. Rosenbaum, P.R. and Rubin, D.B. (1983), The central role of the propensity score in observational studies for causal effects, Biometrika, vol. 70, no. 1, pp. 41-55, DOI: 10.1093/biomet/70.1.41.

34. Stock, J.H. and Watson, M.W. (2003), Introduction to econometrics, Boston, Editura Addison Wesley.

35. Trabelsi, R. (2015), International accounting normalization and harmonization processes across the world: History and overview, GSTF Business Review, vol. 4, no. 2, pp. 54-61, DOl: 10.7603/s40706-015-0023-4.

36. Tucker, J.W. (2011), Selection bias and econometric remedies in accounting and finance research, Journal of Accounting Literature, vol. 29, no. 1, pp. 31-57.

37. Urkaregi, A., Martinez-Indart, L. and Pijoán, J.I. (2014), Balancing properties. A need for the application of propensity score methods in estimation of treatment effects, SORT-Statistics and Operations Research Transactions, vol. 38, no. 2, pp. 271-284.

38. Yu, G. and Wahid, A.S. (2014), Accounting standards and international portfolio holdings, The Accounting Review, vol. 89, no. 5, pp. 1895-1930, DOI: $10.2308 / a c c r-50801$.

39. Zeghal, D. and Mhedhbi, K. (2006), An analysis of the factors affecting the adoption of international accounting standards by developing countries, The International Journal of Accounting, vol. 41, no. 4, pp. 373-386, DOI:10.1016/j.intacc.2006.09.009. 